\title{
Perancangan dan Implementasi Finite Automata pada Simulasi Vending Machine
}

\author{
${ }^{1)}$ Jessica Christiani Irawan, ${ }^{2)}$ M. A. Ineke Pakereng, ${ }^{3)}$ Ramos Somya \\ ${ }^{1)}$ Fakultas Teknologi Informasi, Unive rsitas Kristen Satya Wacana, Jl. Diponegoro 52-60, \\ Salatiga 50771, Indonesia, jck-catrise@yahoo.co.id, \\ ${ }^{2)}$ Fakultas Teknologi Informasi, Universitas Kristen Satya Wacana, Jl. Diponegoro 52-60, \\ Salatiga 50771, Indonesia, inekep200472@ yahoo.com \\ ${ }^{3)}$ Fakultas Teknologi Informasi, Universitas Kris ten Satya Wacana, Jl. Diponegoro 52-60, \\ Salatiga 50771, Indonesia, ramos.somya@gmail.com
}

\begin{abstract}
Language and Automata Theory is one of information technology's component. This theory is the based of ideas and model of a computation system. One example of the Automata implementation is a vending machine. A vending machine can sell goods to customers without an operator to operate the machine. However, in Indonesia,the presence of vending machines are rarely seen. In this study, the author will try to learn about how a vending machine works, as well as to apply part of the Language and Automata Theory to design and create a simulation of a vending machine. As the result of the design and implementation of Finite Automata in vending machine simulation, it can be concluded that Finite Automata can be used for basic logic to make a vending machine simulation. Through this application simulation, user can get an experience in operating a vending machine and leam how to use the vending machine.
\end{abstract}

Keywords: Language and Automata Theory, Finite Automata, Vending Machine, Simulation.

\section{Abstrak}

Teori bahasa dan automata merupakan salah satu komponen ilmu informatika. Teori inilah yang mendasari ide dan model dari sebuah sistem komputasi. Salah satu contoh penerapan automata adalah pada vending machine. Vending machine dapat menjual barang-barang untuk konsumen tanpa adanya seorang operator. Namun, di Indonesia, keberadaan vending machine masih dapat dikatakan langka. Dalam penelitian ini, akan dipelajari cara kerja vending machine, sekaligus diterapkan bagian dari Teori Bahasa dan Automata untuk merancang dan membuat simulasinya. Berdasarkan hasil perancangan dan implementasi Finite Automata pada simulasi vending machine, dapat diambil kesimpulan bahwa Finite Automata dapat dijadikan sebagai logika dasar untuk membuat simulasi vending machine. Melalui aplikasi simulasi ini, diharapkan user dapat memperoleh pengalaman dalam mengoperasikan sebuah vending machine serta mengetahui cara menggunakan sebuah vending machine.

Kata Kunci : Teori Bahasa dan Automata, Finite Automata, Vending Machine, Simulasi.

\section{Pendahuluan}

Penggunaan automata pada perangkat lunak terutama pada pembuatan kompiler bahasa pemrograman. Bahasa pemprograman bertindak sebagai sarana komunikasi antara manus ia dan permasalahannya dengan komputer, yang dipakai untuk membantu memperoleh pemecahan. Sebagai keluaran dari automata, bahasa memungkinkan penyampaian gagasan dan pemikiran manusia, sedangkan sebagai ilmu yang juga mempelajari mengenai mesin abstrak, automata dapat membaca input berupa string dari alphabet yang diberikan dari inputfile.

Salah satu contoh penerapan automata adalah pada vending machine. Vending machine dapat menjual barang-barang untuk konsumen tanpa adanya seorang operator. Sebuah vending machine biasanya menjual satu macam barang, misalnya makanan ringan, minuman, koran, dan lain sebagainya Konsumen yang ingin memperoleh barang yang ada di vending machine tersebut harus memasukkan uang sejumlah harga yang tertera ke lubang uang yang tersedia pada vending machine itu, kemudian menekan tombol barang yang dipilih, dan barang tersebut akan keluar.

Namun, di Indonesia, keberadaan vending machine masih dapat dikatakan langka. Oleh karena itu, muncullah sebuah keinginan untuk mencoba mempelajari cara kerja vending 
machine, sekaligus menerapkan bagian dari Teori Bahasa dan Automata untuk merancang dan membuat simulasinya.

\section{Kajian Pustaka}

Contoh penerapan Teori Bahasa dan Automata adalah Penggunaan Algoritma Greedy Dalam Aplikasi Vending Machine. Pada penerapan ini ditekankan mengenai cara agar sebuah vending machine dapat memberikan uang kembalian secara optimal. Yang dimaksud optimal adalah uang kembalian mempunyai jumlah koin paling sedikit diantara semua kemungkinan uang kembalian. Algoritma Greedy bisa diterapkan sebagai salah satu cara untuk menye lesaikan jumlah uang kembalian tersebut [3].

Melalui penelitian ini, akan dirancang dan diimplementasikan Finite Automata pada simulasi vending machine.

\section{Konsep Bahasa dan Automata}

Teori Bahasa dan Automata termasuk pada komponen pertama dari dua komponen tersebut. Teori Bahasa dan Automata banyak diterapkan pada perancangan digital, pembuatan bahasa pemrograman, dan kompilator [4].

Automata merupakan suatu sistem yang terdiri atas sejumlah state berhingga, dimana setiap state menyatakan informasi mengenai input sebelumnya, dan dapat pula dianggap sebagai memori mesin [6].

Input pada mesin automata dianggap sebagai bahasa yang harus dikenali oleh mesin. Selanjutnya mesin automata membuat keputusan yang mengindikasikan diterima atau tidaknya input tersebut, sehingga mesin automata dapat dipakai untuk menghasilkan suatu bahasa yang aturannya ditentukan oleh bahasa tersebut.

\section{Finite Automata}

Finite Automata (FA), yang bisa disebut juga sebagai Finite State Automata (FSA), automata dengan state berhingga, merupakan suatu model matematika dari suatu sistem yang menerima input dan menghasilkan output diskrit [5]. FA memiliki state yang banyaknya berhingga (terbatas), dan dapat berpindah-pindah dari satu state ke state lain. Perubahan state ini dinyatakan dengan fungsi transisi. State adalah kondisi atau keadaan atau kedudukan.

Sebuah Finite Automata $\mathrm{M}$ dinyatakan dengan lima tupel, yaitu $(\mathrm{Q}, \Sigma, \delta, \mathrm{S}, \mathrm{F})$, di mana: $\mathrm{Q}=$ himpunan state, $\Sigma=$ himpunan alfabet masukan, $\delta=$ fungsi transisi, $\mathrm{S}=$ state awal (initial state), $\mathrm{F}=$ himpunan state akhir (final state)

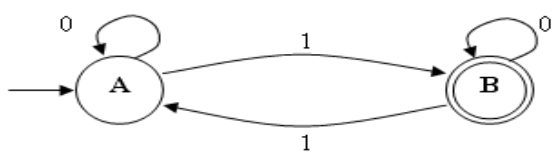

Gambar 1 Contoh State Diagram Finite Automata

- Gambar lingkaran menyatakan state

- Label pada lingkaran adalah nama state tersebut

- Busur panah menyatakan transisi atau perpindahan state

- Gambar lingkaran yang didahului sebuah busur panah tanpa label menyatakan state awal

- Gambar lingkaran ganda menyatakan final state

Maka: $\mathrm{Q}=\{\mathrm{A}, \mathrm{B}\}, \Sigma=\{0,1\}, \mathrm{S}=\{\mathrm{A}\}, \mathrm{F}=\{\mathrm{B}\}$

$\delta=$ fungsi transisi

$\delta(\mathrm{A}, 0)=\mathrm{A}, \delta(\mathrm{A}, 1)=\mathrm{B}, \delta(\mathrm{B}, 0)=\mathrm{B}, \delta(\mathrm{B}, 1)=\mathrm{A}$

Dari fungsi transisi tersebut, dapat dibuat tabel transisi seperti pada Tabel 1.

Tabel 1 Tabel Transisi Berdasarkan Gambar 1

\begin{tabular}{ccc}
\hline $\boldsymbol{\delta}$ & $\mathbf{0}$ & $\mathbf{1}$ \\
\hline $\mathrm{A}$ & $\mathrm{A}$ & $\mathrm{B}$ \\
$\mathrm{B}$ & $\mathrm{B}$ & $\mathrm{A}$ \\
\hline
\end{tabular}


Contoh bila string yang masuk adalah 1011, maka string tersebut bergerak dari Start ke state A, kemudian membaca karakter ' 1 ' dan berpindah ke state B, yang merupakan state tujuan dari hasil pembacaan karakter ' 1 '. Kemudian string selanjutnya yang dibaca adalah '0'. Karena state tujuan dari pembacaan karakter ' 0 ' adalah B sendiri, maka state tidak berpindah. Selanjutnya membaca karakter '1'. Dari state B berpindah ke state A yang merupakan state tujuan setelah membaca karakter '1'. Setelah itu, karakter '1' dibaca dan state berpindah ke state B. Pembacaan string berhenti karena karakter sudah habis. State terakhir yang ditempati adalah state B. Karena state B berada dalam himpunan final state, maka string '1011' diterima oleh Finite Automata tersebut.

\section{Simulasi}

Simulasi adalah tiruan dari proses dunia nyata atau sistem. Simulasi menyangkut pembangkitan proses serta pengamatan dari proses untuk menarik kesimpulan dari sistem yang diwakili. Simulasi mempelajari atau memprediksi sesuatu yang belum terjadi dengan cara meniru atau membuat model sistem yang dipe lajari. [7]

\section{Vending Machine}

Sebuah vending machine memungkinkan seseorang untuk membeli barang yang terdapat di dalam mesin tersebut secara otomatis, tanpa adanya seorang penjaga atau kasir, yang menjadi perantara proses jual-beli tersebut. Proses penjua lan ditangani sepenuhnya oleh mesin. Pembeli hanya tinggal memasukkan uang dan memilih barang yang akan dibeli.

Vending machine pertama yang ditemukan adalah hasil karya Hero dari Alexandria, seorang ahli mesin dan matematika pada abad pertama. Mesin tersebut dapat menerima koin, lalu mengeluarkan air suci dalam jumlah tertentu. Cara kerjanya masih dibilang sederhana. Ketika koin dimasukkan, koin tersebut jatuh ke dalam sebuah panci yang terhubung dengan tuas. Tuas tersebut kemudian membuka sebuah katup yang membuat sejumlah a ir keluar. Panci tersebut akan terus miring akibat berat koin, sampai akhirnya koin tersebut jatuh dan mengembalikan posisi tuas serta menutup katup air [8].

\section{Perancangan Sistem}

Sistem dirancang dengan menggunakan UML (Unified Modelling Language) yang terdiri dari use case diagram, activity diagram, sequence diagram, class diagram dan deployment diagram.

Sebuah use case diagram berfungsi untuk mendeskripsikan tindakan sistem dari sudut pandang user, sebagai deskripsi fungsional dari sebuah sistem dan proses utamanya, serta menjelaskan secara visual siapa yang menggunakan sistem dan bagaimana interaksinya. Aplikasi simulasi vending machine ini digunakan oleh user yang terdiri dari user dan admin. Use case diagram untuk user dapat dilihat pada Gambar 2.
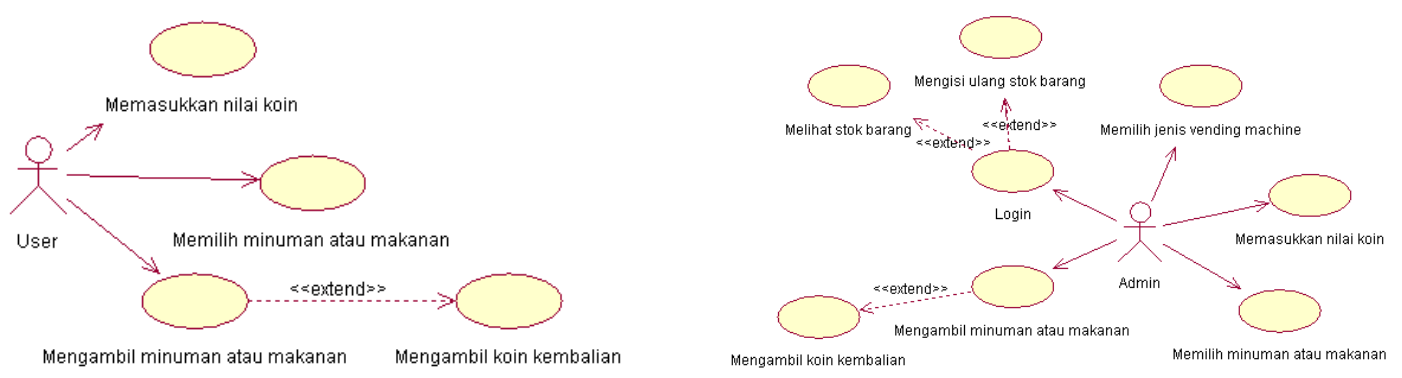

Gambar 2 (a) Use Case Diagram User (b) Use Case Diagram Admin

Setelah menjalankan aplikasi, user dapat memakai fasilitas yang dapat dilakukan terhadap aplikasi, seperti memilih jenis vending machine, memasukkan nilai koin untuk memulai simulasi, memilih jenis minuman atau makanan yang akan dibeli, mengambil minuman atau makanan yang keluar jika proses transaksi berhasil, dan juga mengambil kembalian jika ternyata nilai uang yang dimasukkan berlebih. 
Use case diagram untuk admin dapat dilihat pada Gambar 2(b). Sebenarnya tugas utama admin berkaitan dengan stok barang yang ada pada database, yaitu mengawasi stok barang pada vending machine. Untuk memperoleh akses ke database, admin harus melakukan login terlebih dahulu. Setelah itu, barulah admin dapat melihat stok barang dan menggunakan fasilitas isi ulang stok barang (re-stok) bila stok barang di vending machine sudah habis. Dapat menjalankan simulasi vending machine merupakan fasilitas tambahan bagi admin.

Activity diagram menggambarkan aliran aktivitas dalam sistem yang sedang dirancang, bagaimana masing-masing aliran dimulai, apa keputusan yang terjadi, dan bagaimana aktivitas tersebut berakhir.

Jika aplikasi simulasi ini digunakan oleh user, maka proses interaksi antara user dengan aplikasi simulasi vending machine dapat digambarkan seperti pada Gambar 3.

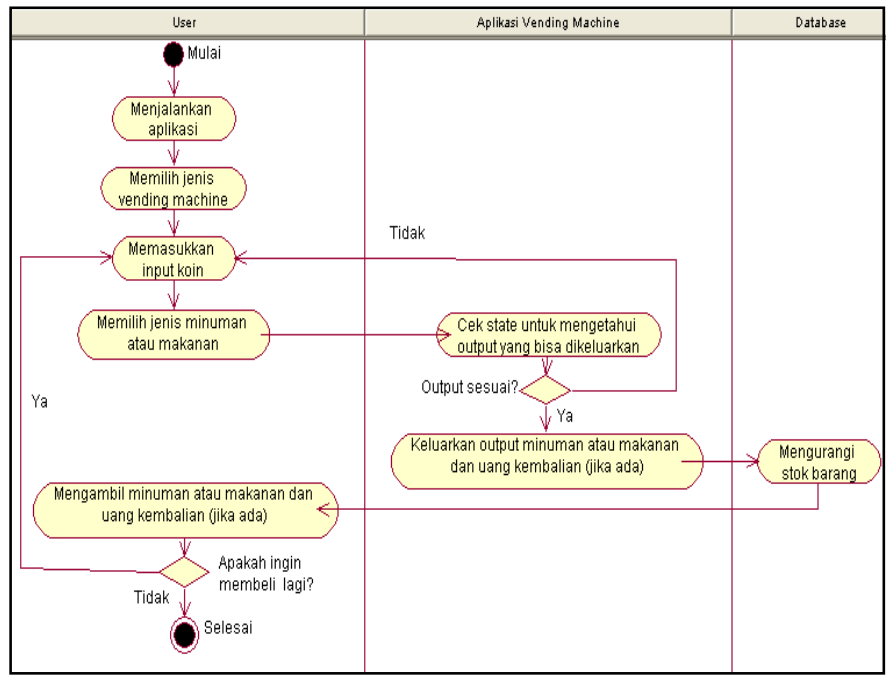

Gambar 3 Activity Diagram Interaksi User dengan Aplikasi Vending Machine

User memulai simulasi dengan menjalankan aplikasi vending machine. Kemudian user dapat memilih jenis vending machine yang akan dijalankan, yaitu vending machine minuman ringan atau makanan ringan. Setelah aplikasi vending machine muncul, user dapat memasukkan nilai koin pada aplikasi tersebut.

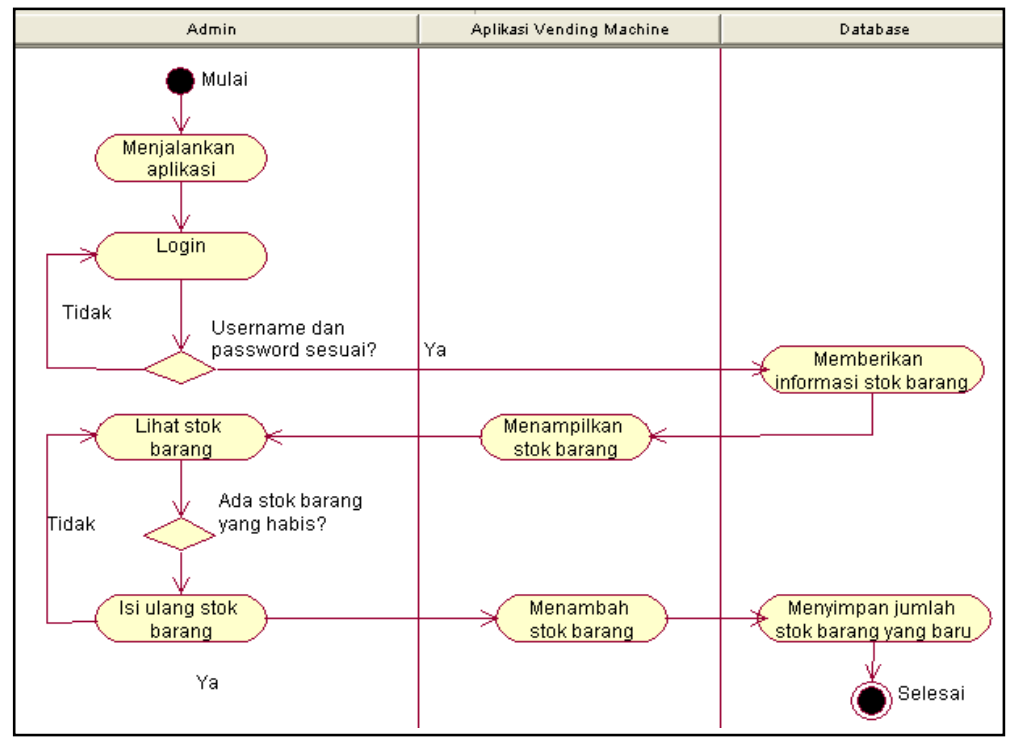

Gambar 4 Activity Diagram Admin 
Gambar 4 menjelaskan activity diagram untuk tugas utama admin. Admin menjalankan aplikasi, lalu untuk mengakses database, admin harus melakukan login terlebih dahulu. Jika username dan password yang diisikan sesuai, maka admin dapat melihat stok barang yang ada di database. Jika ada barang yang stoknya habis, maka admin dapat mengisi ulang stok barang tersebut dan data jumlah barang di database akan diperbaharui.
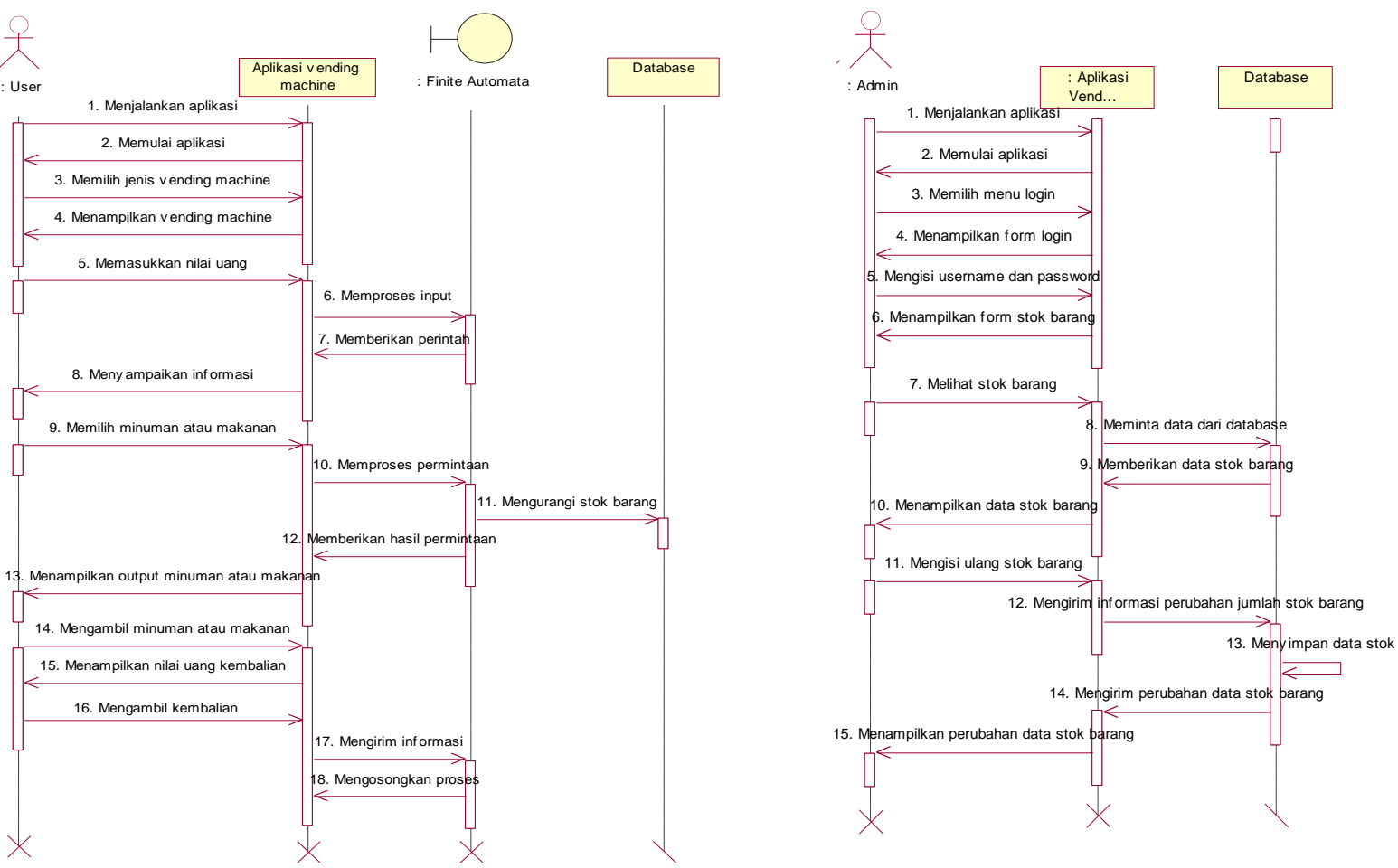

Gambar 5 (a) Sequence Diagram Interaksi User dengan Aplikasi Vending Machine, (b) Sequence Diagram Admin

Gambar 5 (a) merupakan sequence diagram user yang berinteraksi dengan aplikasi simulasi vending machine. Pada diagram tersebut, user menjalankan aplikasi, memilih jenis vending machine (minuman ringan atau makanan ringan), lalu memberikan input kepada aplikasi berupa nilai uang koin. Aplikasi menerima input tersebut lalu memprosesnya dengan Finite Automata. Aplikasi memberikan informasi kepada user mengenai jumlah uang yang dimasukkan. Jika melihat jumlah uang sudah cukup, maka user memilih minuman atau makanan yang akan dibeli. Aplikasi kembali memproses permintaan tersebut dengan Finite Automata. Output minuman keluar. User mengambil minuman atau makanan tersebut berikut kembaliannya, dan aplikasi mengirim informasi bahwa proses sudah selesai. Proses simulasi dikosongkan dan dimulai dari awal lagi.

Pada Gambar 5(b) ditunjukkan sequence diagram admin yang berinteraksi dengan aplikasi simulasi vending machine. Admin menjalankan aplikasi, lalu melakukan login. Setelah itu, admin dapat melihat isi database stok barang pada vending machine dengan perantara aplikasi. Jika perlu mengisi ulang stok barang, maka admin dapat menggunakan fasilitas re-stok dan database akan menyimpan jumlah stok barang yang baru. Pembaharuan data ini kemudian akan ditampilkan kembali kepada admin .

Class diagram menggambarkan struktur dan deskripsi, class, package, serta hubungannya satu sama lain. Class diagram ditampilkan dalam beberapa kelas serta paket yang ada dalam sistem yang sedang dikembangkan. Gambar 6(a) merupakan class diagram sistem pada proses simulasi vending machine.

Dari Gambar 6(a) dapat diketahui bahwa class simulasi vending machine memiliki atribut input, output, dan stok. Atribut-atribut ini berfungsi untuk menyimpan data untuk proses simulasi. Atribut input menampung input yang diberikan user pada aplikasi, lalu mengirimkan input tersebut ke class State dengan method KirimInput().Method AmbilOutput() akan 
mengambil output dari class State, sedangkan AmbilStok() berfungsi untuk mengambil jumlah stok barang yang ada di database.
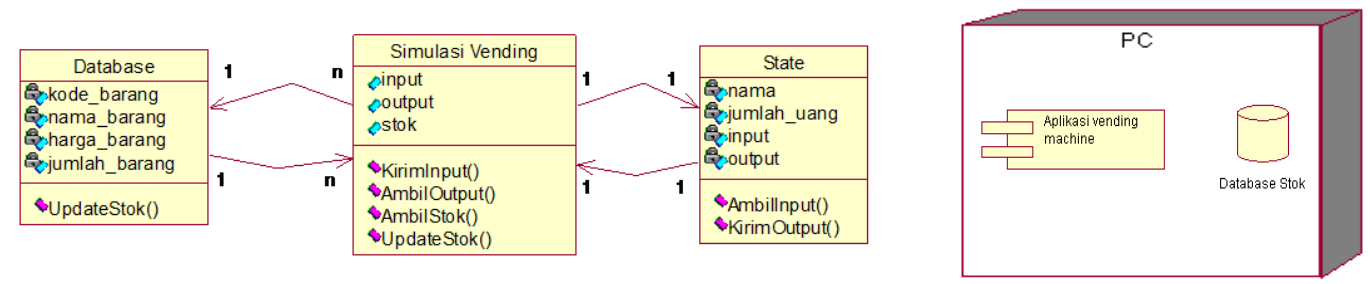

Gambar 6 (a) Class Diagram Sistem, (b) Deployment Diagram Sistem

UpdateStok() berfungsi untuk memperbaharui jumlah barang yang ada di database bila user melakukan pembelian di vending machine. Class State memiliki atribut nama, yaitu nama state, lalu jumlah_uang untuk mendeklarasikan jumlah uang yang ada pada state tersebut, dan juga input dan output, yang berfungsi untuk menampung input dari class Simulasi Vending yang diterima oleh method Ambillnput() dan mendefinisikan output yang harus dike luarkan menurut input yang didapat dan mengirimkannya ke class Simulasi Vending dengan method KirimOutput(). Sementara itu database memiliki field tabel kode_barang, nama_barang, harga_barang, dan juga jumlah_barang untuk mengidentifikasi stok barang. Operasi yang dibutuhkan untuk database ini adalah UpdateStok() untuk memperbaharui jumlah stok barang.

Deployment diagram berfungsi untuk menampilkan rancangan fisik jaringan dalam sistem. Gambar 6 (b) adalah deployment diagram sistem bila aplikasi simulasi vending machine dibuat dalam sebuah jaringan. Pada Gambar 6(b), yang dibutuhkan hanyalah sebuah PC untuk menjalankan aplikasi simulasi vending machine. Pada PC tersebut terdapat dua buah kompunen, yaitu aplikasi vending machine dan basisdata untuk menyimpan data stok barang.

\section{Perancangan Antarmuka Aplikasi}

Rancangan interface (antarmuka) aplikasi simulasi vending machine yang akan dibuat adalah seperti yang ditunjukkan Gambar 7.

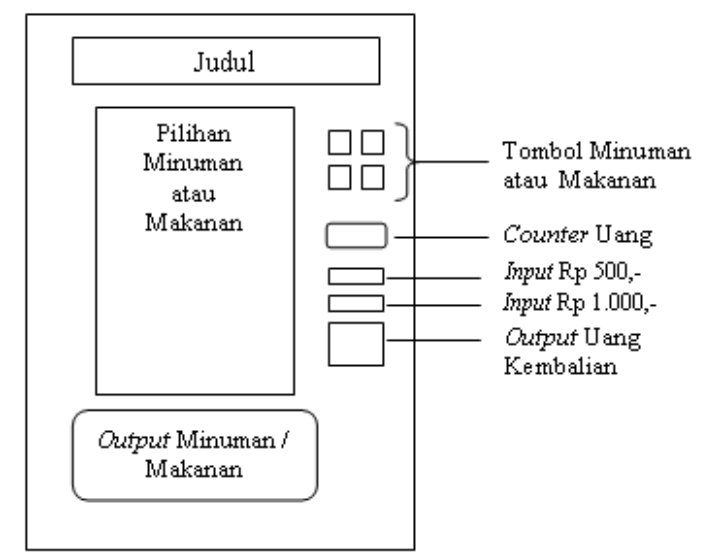

Gambar 7 Rancangan Antarmuka Aplikasi Vending Machine

\section{Perancangan Prototype}

Rencana proses langkah kerja aplikasi simulasi vending machine adalah seperti yang ditunjukkan pada Gambar 8.

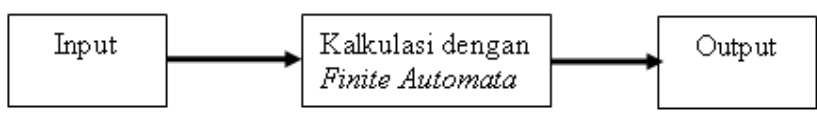

Gambar 8 Langkah-langkah Kerja Aplikasi Simu lasi Vending Machine 
Keterangan proses pada Gambar 8 tersebut adalah a) Input: Input berupa masukan angka 500 atau 1000 sebagai uang, serta jenis minuman atau makanan yang dimasukkan oleh user yang ingin mencoba simulasi vending machine. b) Kalkulasi dengan Finite Automata: Setelah input selesai dimasukkan, program akan melakukan proses kalkulasi sesuai konsep Mealy machine untuk menentukan output apa yang akan dikeluarkan oleh vending machine tersebut sesuai dengan input yang diterima. Agar dapat melaksanakan proses kalkulasi sesuai konsep Mealy machine, perlu dilakukan tahap-tahap sebagai berikut:

\section{Me rancang diagram state}

Untuk memulai rancangan prototype aplikasi, yang perlu dilakukan adalah membuat sebuah diagram state sebagai patokan pendefinisian tupel dan alur program.

Pada batasan masalah telah disebutkan bahwa input adalah uang koin $\mathrm{Rp} 500$,- dan $\mathrm{Rp}$ $1.000,-$, dan outputnya adalah empat macam minuman ringan atau makanan ringan. Empat macam minuman tersebut adalah Frestea kotak seharga 2.500 rupiah, Sprite, Fanta dan CocaCola kaleng seharga 3.000 rupiah. Sedangkan empat macam makanan ringannya adalah Cheetos dan JetZ seharga 1.000 rupiah, serta Lays dan Chitato seharga 1.500 rupiah. Berdasarkan batasan masalah tersebut, maka dapat dibuat diagram state seperti Gambar 9.

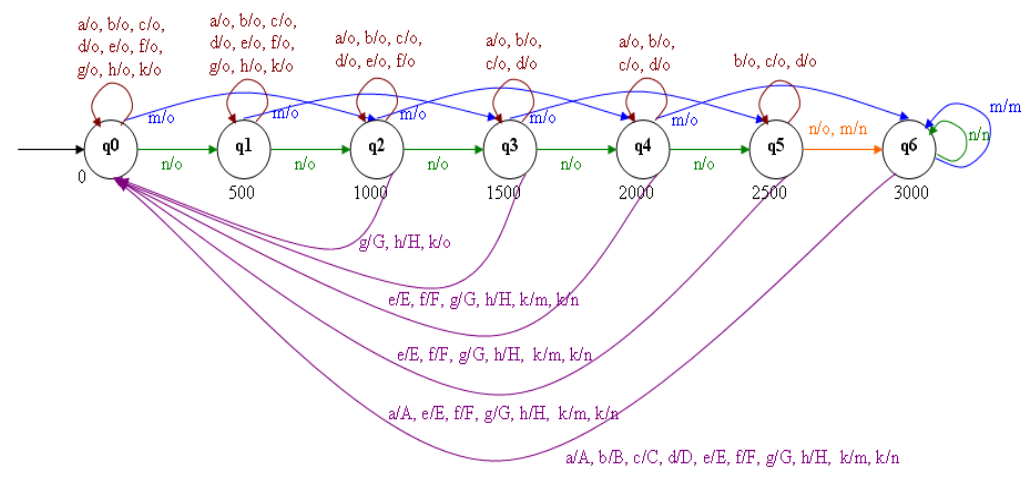

Gambar 9 Rancangan Diagram State Simu lasi Vending Machine

Ada sebelas input pada mesin ini, yaitu a (memilih Frestea), b (memilih Fanta), c (memilih Coca-cola), d (memilih Sprite), e (memilih Lays), f (memilih Chitato), g (memilih Cheetos), h (memilih JetZ), m (uang koin Rp 1.000,-), n (uang koin Rp 500,-), dan k (mengambil uang kembalian).

Sedangkan outputnya ada sembilan, antara lain A (mengeluarkan Frestea), B (mengeluarkan Sprite), C (mengeluarkan Sprite), D (mengeluarkan Coca-Cola), E (mengeluarkan Lays), F (mengeluarkan Chitato), G (mengeluarkan Cheetos), H (mengeluarkan JetZ), dan o (tidak melakukan apa-apa).

\section{Mendefinisikan tupel}

Mealy machine didefinisikan dengan enam tupel, dengan rumus:

Dimana:

$$
\mathrm{Me}=(\mathrm{Q}, \Sigma, \delta, \mathrm{S}, \Delta, \lambda)
$$

$\mathrm{Q}=$ himpunan state, $\Sigma=$ himpunan simbol input, $\delta=$ fungsi transisi $(\delta: \mathrm{Q} \times \Sigma \rightarrow \mathrm{Q}), \mathrm{S}=$ state awal (initial state), $\Delta=$ himpunan simbol output, $\lambda=$ fungsi output untuk setiap transisi $(\delta$ $: \mathrm{Q} \times \Sigma \rightarrow \Delta$ )

Sehingga dapat dibuat definisi sebagai berikut:

$\mathrm{Q}=\{\mathrm{q} 0, \mathrm{q} 1, \mathrm{q} 2, \mathrm{q} 3, \mathrm{q} 4, \mathrm{q} 5, \mathrm{q} 6\}$

$\Sigma=\{\mathrm{a}, \mathrm{b}, \mathrm{c}, \mathrm{d}, \mathrm{e}, \mathrm{f}, \mathrm{g}, \mathrm{h}, \mathrm{m}, \mathrm{n}, \mathrm{k}\}$

$\delta=$ fungsi transisi

$$
\begin{aligned}
& \delta(\mathrm{q} 0, \mathrm{a})=\mathrm{q} 0 ; \delta(\mathrm{q} 0, \mathrm{~b})=\mathrm{q} 0 ; \delta(\mathrm{q} 0, \mathrm{c})=\mathrm{q} 0 ; \delta(\mathrm{q} 0, \mathrm{~d})=\mathrm{q} 0 ; \delta(\mathrm{q} 0, \mathrm{e})=\mathrm{q} 0 ; \delta(\mathrm{q} 0, \mathrm{f})=\mathrm{q} 0 \\
& \delta(\mathrm{q} 0, \mathrm{~g})=\mathrm{q} 0 ; \delta(\mathrm{q} 0, \mathrm{~h})=\mathrm{q} 0 ; \delta(\mathrm{q} 0, \mathrm{~m})=\mathrm{q} 2 ; \delta(\mathrm{q} 0, \mathrm{n})=\mathrm{q} 1 ; \delta(\mathrm{q} 0, \mathrm{k})=\mathrm{q} 0 \\
& \delta(\mathrm{q} 1, \mathrm{a})=\mathrm{q} 1 ; \delta(\mathrm{q} 1, \mathrm{~b})=\mathrm{q} 0 ; \delta(\mathrm{q} 1, \mathrm{c})=\mathrm{q} 1 ; \delta(\mathrm{q} 1, \mathrm{~d})=\mathrm{q} 1 ; \delta(\mathrm{q} 1, \mathrm{e})=\mathrm{q} 1 ; \delta(\mathrm{q} 1, \mathrm{f})=\mathrm{q} 0 \\
& \delta(\mathrm{q} 1, \mathrm{~g})=\mathrm{q} 1 ; \delta(\mathrm{q} 1, \mathrm{~h})=\mathrm{q} 1 ; \delta(\mathrm{q} 1, \mathrm{~m})=\mathrm{q} 3 ; \delta(\mathrm{q} 1, \mathrm{n})=\mathrm{q} 2 ; \delta(\mathrm{q} 1, \mathrm{k})=\mathrm{q} 1 ;
\end{aligned}
$$


$\delta(\mathrm{q} 2, \mathrm{a})=\mathrm{q} 2 ; \delta(\mathrm{q} 2, \mathrm{~b})=\mathrm{q} 2 ; \delta(\mathrm{q} 2, \mathrm{c})=\mathrm{q} 2 ; \delta(\mathrm{q} 2, \mathrm{~d})=\mathrm{q} 2 ; \delta(\mathrm{q} 2, \mathrm{e})=\mathrm{q} 2 ; \delta(\mathrm{q} 2, \mathrm{f})=\mathrm{q} 2 ;$ $\delta(\mathrm{q} 2, \mathrm{~g})=\mathrm{q} 0 ; \delta(\mathrm{q} 2, \mathrm{~h})=\mathrm{q} 0 ; \delta(\mathrm{q} 2, \mathrm{~m})=\mathrm{q} 4 ; \delta(\mathrm{q} 2, \mathrm{n})=\mathrm{q} 3 ; \delta(\mathrm{q} 2, \mathrm{k})=\mathrm{q} 0 ;$

$\delta(\mathrm{q} 3, \mathrm{a})=\mathrm{q} 3 ; \delta(\mathrm{q} 3, \mathrm{~b})=\mathrm{q} 3 ; \delta(\mathrm{q} 3, \mathrm{c})=\mathrm{q} 3 ; \delta(\mathrm{q} 3, \mathrm{~d})=\mathrm{q} 3 ; \delta(\mathrm{q} 3, \mathrm{e})=\mathrm{q} 0 ; \delta(\mathrm{q} 3, \mathrm{f})=\mathrm{q} 0 ;$ $\delta(\mathrm{q} 3, \mathrm{~g})=\mathrm{q} 0 ; \delta(\mathrm{q} 3, \mathrm{~h})=\mathrm{q} 0 ; \delta(\mathrm{q} 3, \mathrm{~m})=\mathrm{q} 5 ; \delta(\mathrm{q} 3, \mathrm{n})=\mathrm{q} 4 ; \delta(\mathrm{q} 3, \mathrm{k})=\mathrm{q} 0 ;$

$\delta(\mathrm{q} 4, \mathrm{a})=\mathrm{q} 4 ; \delta(\mathrm{q} 4, \mathrm{~b})=\mathrm{q} 4 ; \delta(\mathrm{q} 4, \mathrm{c})=\mathrm{q} 4 ; \delta(\mathrm{q} 4, \mathrm{~d})=\mathrm{q} 4 ; \delta(\mathrm{q} 4, \mathrm{e})=\mathrm{q} 0 ; \delta(\mathrm{q} 4, \mathrm{f})=\mathrm{q} 0 ;$ $\delta(\mathrm{q} 4, \mathrm{~g})=\mathrm{q} 0 ; \delta(\mathrm{q} 4, \mathrm{~h})=\mathrm{q} 0 ; \delta(\mathrm{q} 4, \mathrm{~m})=\mathrm{q} 6 ; \delta(\mathrm{q} 4, \mathrm{n})=\mathrm{q} 5 ; \delta(\mathrm{q} 4, \mathrm{k})=\mathrm{q} 0 ;$

$\delta(\mathrm{q} 5, \mathrm{a})=\mathrm{q} 0 ; \delta(\mathrm{q} 5, \mathrm{~b})=\mathrm{q} 5 ; \delta(\mathrm{q} 5, \mathrm{c})=\mathrm{q} 5 ; \delta(\mathrm{q} 5, \mathrm{~d})=\mathrm{q} 5 ; \delta(\mathrm{q} 5, \mathrm{e})=\mathrm{q} 0 ; \delta(\mathrm{q} 5, \mathrm{f})=\mathrm{q} 0 ;$ $\delta(\mathrm{q} 5, \mathrm{~g})=\mathrm{q} 0 ; \delta(\mathrm{q} 5, \mathrm{~h})=\mathrm{q} 0 ; \delta(\mathrm{q} 5, \mathrm{~m})=\mathrm{q} 6 ; \delta(\mathrm{q} 5, \mathrm{n})=\mathrm{q} 6 ; \delta(\mathrm{q} 0, \mathrm{k})=\mathrm{q} 0 ;$

$\delta(\mathrm{q} 6, \mathrm{a})=\mathrm{q} 0 ; \delta(\mathrm{q} 6, \mathrm{~b})=\mathrm{q} 0 ; \delta(\mathrm{q} 6, \mathrm{c})=\mathrm{q} 0 ; \delta(\mathrm{q} 6, \mathrm{~d})=\mathrm{q} 0 ; \delta(\mathrm{q} 6, \mathrm{e})=\mathrm{q} 0 ; \delta(\mathrm{q} 6, \mathrm{f})=\mathrm{q} 0 ;$ $\delta(\mathrm{q} 6, \mathrm{~g})=\mathrm{q} 0 ; \delta(\mathrm{q} 6, \mathrm{~h})=\mathrm{q} 0 ; \delta(\mathrm{q} 6, \mathrm{~m})=\mathrm{q} 6 ; \delta(\mathrm{q} 6, \mathrm{n})=\mathrm{q} 6 ; \delta(\mathrm{q} 6, \mathrm{k})=\mathrm{q} 0 ;$

Bila dipetakan dalam tabel, menjadi seperti pada Tabel 4.

Tabel 4 Tabel Transisi Input

\begin{tabular}{cccccccccccc}
\hline $\boldsymbol{\delta}$ & $\mathbf{a}$ & $\mathbf{b}$ & $\mathbf{c}$ & $\mathbf{d}$ & $\mathbf{e}$ & $\mathbf{f}$ & $\mathbf{g}$ & $\mathbf{h}$ & $\mathbf{m}$ & $\mathbf{n}$ & $\mathbf{k}$ \\
\hline $\mathrm{q} 0$ & $\mathrm{q} 0$ & $\mathrm{q} 0$ & $\mathrm{q} 0$ & $\mathrm{q} 0$ & $\mathrm{q} 0$ & $\mathrm{q} 0$ & $\mathrm{q} 0$ & $\mathrm{q} 0$ & $\mathrm{q} 2$ & $\mathrm{q} 1$ & $\mathrm{q} 0$ \\
$\mathrm{q} 1$ & $\mathrm{q} 1$ & $\mathrm{q} 1$ & $\mathrm{q} 1$ & $\mathrm{q} 1$ & $\mathrm{q} 1$ & $\mathrm{q} 1$ & $\mathrm{q} 1$ & $\mathrm{q} 1$ & $\mathrm{q} 3$ & $\mathrm{q} 2$ & $\mathrm{q} 1$ \\
$\mathrm{q} 2$ & $\mathrm{q} 2$ & $\mathrm{q} 2$ & $\mathrm{q} 2$ & $\mathrm{q} 2$ & $\mathrm{q} 2$ & $\mathrm{q} 2$ & $\mathrm{q} 0$ & $\mathrm{q} 0$ & $\mathrm{q} 4$ & $\mathrm{q} 3$ & $\mathrm{q} 0$ \\
$\mathrm{q} 3$ & $\mathrm{q} 3$ & $\mathrm{q} 3$ & $\mathrm{q} 3$ & $\mathrm{q} 3$ & $\mathrm{q} 0$ & $\mathrm{q} 0$ & $\mathrm{q} 0$ & $\mathrm{q} 0$ & $\mathrm{q} 5$ & $\mathrm{q} 4$ & $\mathrm{q} 0$ \\
$\mathrm{q} 4$ & $\mathrm{q} 4$ & $\mathrm{q} 4$ & $\mathrm{q} 4$ & $\mathrm{q} 4$ & $\mathrm{q} 0$ & $\mathrm{q} 0$ & $\mathrm{q} 0$ & $\mathrm{q} 0$ & $\mathrm{q} 6$ & $\mathrm{q} 5$ & $\mathrm{q} 0$ \\
$\mathrm{q} 5$ & $\mathrm{q} 0$ & $\mathrm{q} 5$ & $\mathrm{q} 5$ & $\mathrm{q} 5$ & $\mathrm{q} 0$ & $\mathrm{q} 0$ & $\mathrm{q} 0$ & $\mathrm{q} 0$ & $\mathrm{q} 6$ & $\mathrm{q} 6$ & $\mathrm{q} 0$ \\
$\mathrm{q} 6$ & $\mathrm{q} 0$ & $\mathrm{q} 0$ & $\mathrm{q} 0$ & $\mathrm{q} 0$ & $\mathrm{q} 0$ & $\mathrm{q} 0$ & $\mathrm{q} 0$ & $\mathrm{q} 0$ & $\mathrm{q} 6$ & $\mathrm{q} 6$ & $\mathrm{q} 0$ \\
\hline
\end{tabular}

Tabel 4 menjelaskan tentang transisi input, yaitu perpindahan state apabila ada input tertentu yang masuk.

\begin{tabular}{|c|c|c|c|c|c|c|c|c|c|c|c|}
\hline \multicolumn{12}{|c|}{$S=\{q 0\}$} \\
\hline \multirow{2}{*}{\multicolumn{12}{|c|}{$\begin{array}{l}\Delta=\{\mathrm{A}, \mathrm{B}, \mathrm{C}, \mathrm{D}, \mathrm{o}\} \\
\lambda=\text { fungsi } \text { output untuk setiap transisi }\end{array}$}} \\
\hline & & & & & & & & & & & \\
\hline \multirow{15}{*}{\multicolumn{12}{|c|}{$\begin{array}{l}\lambda(\mathrm{q} 0, \mathrm{a})=\mathrm{o} ; \lambda(\mathrm{q} 0, \mathrm{~b})=\mathrm{o} ; \lambda(\mathrm{q} 0, \mathrm{c})=\mathrm{o} ; \lambda(\mathrm{q} 0, \mathrm{~d})=\mathrm{o} ; \lambda(\mathrm{q} 0, \mathrm{e})=\mathrm{o} ; \lambda \\
\lambda(\mathrm{q} 0, \mathrm{~g})=\mathrm{o} ; \lambda(\mathrm{q} 0, \mathrm{~h})=\mathrm{o} ; \lambda(\mathrm{q} 0, \mathrm{~m})=\mathrm{o} ; \lambda(\mathrm{q} 0, \mathrm{n})=\mathrm{o} ; \lambda(\mathrm{q} 0, \mathrm{k})=\mathrm{o} ; \\
\lambda(\mathrm{q} 1, \mathrm{a})=\mathrm{o} ; \lambda(\mathrm{q} 1, \mathrm{~b})=\mathrm{o} ; \lambda(\mathrm{q} 1, \mathrm{c})=\mathrm{o} ; \lambda(\mathrm{q} 1, \mathrm{~d})=\mathrm{o} ; \lambda(\mathrm{q} 1, \mathrm{e})=\mathrm{o} ; \\
\lambda(\mathrm{q} 1, \mathrm{~g})=\mathrm{o} ; \lambda(\mathrm{q} 1, \mathrm{~h})=\mathrm{o} ; \lambda(\mathrm{q} 1, \mathrm{~m})=\mathrm{o} ; \lambda(\mathrm{q} 1, \mathrm{n})=\mathrm{o} ; \lambda(\mathrm{q} 1, \mathrm{k})=\mathrm{o} ; \\
\lambda(\mathrm{q} 2, \mathrm{a})=\mathrm{o} ; \lambda(\mathrm{q} 2, \mathrm{~b})=\mathrm{o} ; \lambda(\mathrm{q} 2, \mathrm{c})=\mathrm{o} ; \lambda(\mathrm{q} 2, \mathrm{~d})=\mathrm{o} ; \lambda(\mathrm{q} 2, \mathrm{e})=\mathrm{o} ; \lambda \\
\lambda(\mathrm{q} 2, \mathrm{~g})=\mathrm{G} ; \lambda(\mathrm{q} 2, \mathrm{~h})=\mathrm{H} ; \lambda(\mathrm{q} 2, \mathrm{~m})=\mathrm{o} ; \lambda(\mathrm{q} 2, \mathrm{n})=\mathrm{o} ; \lambda(\mathrm{q} 2, \mathrm{k})=\mathrm{o} ; \\
\lambda(\mathrm{q} 3, \mathrm{a})=\mathrm{o} ; \lambda(\mathrm{q} 3, \mathrm{~b})=\mathrm{o} ; \lambda(\mathrm{q} 3, \mathrm{c})=\mathrm{o} ; \lambda(\mathrm{q} 3, \mathrm{~d})=\mathrm{o} ; \lambda(\mathrm{q} 3, \mathrm{e})=\mathrm{E} ; \lambda \\
\lambda(\mathrm{q} 3, \mathrm{~g})=\mathrm{G} ; \lambda(\mathrm{q} 3, \mathrm{~h})=\mathrm{H} ; \lambda(\mathrm{q} 3, \mathrm{~m})=\mathrm{o} ; \lambda(\mathrm{q} 3, \mathrm{n})=\mathrm{o} ; \lambda(\mathrm{q} 3, \mathrm{k})=\mathrm{m}, \mathrm{n} ; \\
\lambda(\mathrm{q} 4, \mathrm{a})=\mathrm{o} ; \lambda(\mathrm{q} 4, \mathrm{~b})=\mathrm{o} ; \lambda(\mathrm{q} 4, \mathrm{c})=\mathrm{o} ; \lambda(\mathrm{q} 4, \mathrm{~d})=\mathrm{o} ; \lambda(\mathrm{q} 4, \mathrm{e})=\mathrm{E} ; \lambda \\
\lambda(\mathrm{q} 4, \mathrm{~g})=\mathrm{G} ; \lambda(\mathrm{q} 4, \mathrm{~h})=\mathrm{H} ; \lambda(\mathrm{q} 4, \mathrm{~m})=\mathrm{o} ; \lambda(\mathrm{q} 4, \mathrm{n})=\mathrm{o} ; \lambda(\mathrm{q} 4, \mathrm{k})=\mathrm{m}, \mathrm{n} ; \\
\lambda(\mathrm{q} 5, \mathrm{a})=\mathrm{A} ; \lambda(\mathrm{q} 5, \mathrm{~b})=\mathrm{o} ; \lambda(\mathrm{q} 5, \mathrm{c})=\mathrm{o} ; \lambda(\mathrm{q} 5, \mathrm{~d})=\mathrm{o} ; \lambda(\mathrm{q} 5, \mathrm{e})=\mathrm{E} ; \lambda \\
\lambda(\mathrm{q} 5, \mathrm{~g})=\mathrm{G} ; \lambda(\mathrm{q} 5, \mathrm{~h})=\mathrm{H} ; \lambda(\mathrm{q} 5, \mathrm{~m})=\mathrm{o} ; \lambda(\mathrm{q} 5, \mathrm{n})=\mathrm{o} ; \lambda(\mathrm{q} 5, \mathrm{k})=\mathrm{m}, \mathrm{n} ; \\
\lambda(\mathrm{q} 6, \mathrm{a})=\mathrm{A} ; \lambda(\mathrm{q} 6, \mathrm{~b})=\mathrm{B} ; \lambda(\mathrm{q} 6, \mathrm{c})=\mathrm{C} ; \lambda(\mathrm{q} 6, \mathrm{~d})=\mathrm{D} ; \lambda(\mathrm{q} 6, \mathrm{e})=\mathrm{E} ; \lambda \\
\lambda(\mathrm{q} 6, \mathrm{~g})=\mathrm{G} ; \lambda(\mathrm{q} 6, \mathrm{~h})=\mathrm{H} ; \lambda(\mathrm{q} 6, \mathrm{~m})=\mathrm{m} ; \lambda(\mathrm{q} 6, \mathrm{n})=\mathrm{n} ; \lambda(\mathrm{q} 6, \mathrm{k})=\mathrm{m}, \mathrm{n} ; \\
\text { Bila dipetakan dalam tabel, menjadi seperti pada Tabel } 5 .\end{array}$}} \\
\hline & & & & & & & & & & & \\
\hline & & & & & & & & & & & \\
\hline & & & & & & & & & & & \\
\hline & & & & & & & & & & & \\
\hline & & & & & & & & & & & \\
\hline & & & & & & & & & & & \\
\hline & & & & & & & & & & & \\
\hline & & & & & & & & & & & \\
\hline & & & & & & & & & & & \\
\hline & & & & & & & & & & & \\
\hline & & & & & & & & & & & \\
\hline & & & & & & & & & & & \\
\hline & & & & & & & & & & & \\
\hline & & & & & & & & & & & \\
\hline \multicolumn{12}{|c|}{ Tabel 5 Tabel Transisi Output } \\
\hline$\delta$ & $\mathbf{a}$ & b & c & d & $\mathbf{e}$ & $\mathbf{f}$ & $\mathbf{g}$ & $\mathbf{h}$ & $\mathbf{m}$ & & $\mathbf{k}$ \\
\hline q0 & o & o & o & o & o & O & o & O & o & & \\
\hline q1 & o & o & o & o & o & o & o & o & o & o & \\
\hline & o & o & o & o & o & o & G & $\mathrm{H}$ & o & o & o \\
\hline $\mathrm{q} 3$ & o & o & o & o & $\mathrm{E}$ & $\mathrm{F}$ & $\mathrm{G}$ & $\mathrm{H}$ & o & $\mathrm{o}$ & $\mathrm{m}, \mathrm{n}$ \\
\hline $\mathrm{q} 4$ & o & o & o & o & $\mathrm{E}$ & $\mathrm{F}$ & $\mathrm{G}$ & $\mathrm{H}$ & o & $\mathrm{o}$ & $\mathrm{m}, \mathrm{n}$ \\
\hline q5 & A & o & o & $\mathrm{o}$ & $\mathrm{E}$ & $\mathrm{F}$ & $\mathrm{G}$ & $\mathrm{H}$ & o & o & $\mathrm{m}, \mathrm{n}$ \\
\hline & A & B & $\mathrm{C}$ & $\mathrm{D}$ & E & $\mathrm{F}$ & $\mathrm{G}$ & $\mathrm{H}$ & $\mathrm{m}$ & $\mathrm{n}$ & $\mathrm{m}, \mathrm{n}$ \\
\hline
\end{tabular}


Tabel 5 menunjukkan transisi output. Lewat Tabel 6 ini, dapat diketahui output apa yang harus dikeluarkan oleh aplikasi vending machine. Contohnya pada state q6. Bila input yang masuk adalah a, sesuai Gambar 13, maka output-nya adalah A (Frestea). Bila mendapat input b, output-nya adalah B (Fanta). Bila mendapat input c, output-nya yaitu C (Coca-Cola). Bila mendapat input d, output-nya adalah D (Sprite). Bila mendapat input e, output-nya adalah E (Lays). Bila mendapat input $\mathrm{f}$, output-nya adalah F (Chitato). Bila mendapat input $\mathrm{g}$, output-nya adalah g (Cheetos). Bila mendapat input $\mathrm{h}$, output-nya adalah $\mathrm{H}$ (JetZ). Bila mendapat input $\mathrm{m}$ (1.000), maka output-nya adalah $\mathrm{m}$ lagi, dan bila inputnya $\mathrm{n}$ (500), output-nya juga $\mathrm{n}$. Sebenarnya state q6 adalah state terakhir, sehingga bila diberi input nilai uang lagi ( $\mathrm{m}$ dan $\mathrm{n}$ ), maka state tidak akan beranjak dan memuat nilai ke lebihan uang tersebut. Bila inputnya adalah $\mathrm{k}$ (mengambil kembalian), maka kelebihan dari $\mathrm{m}$ dan $\mathrm{n}$ tadi akan dikeluarkan sesuai dengan nilainya.

c) Output: Dari hasil kalkulasi, diperoleh output yang akan dikeluarkan aplikasi. Output berupa gambar minuman atau makanan yang dipilih, serta angka yang menyatakan uang kembalian (jika ada).

\section{Hasil dan Pembahasan}

\section{Form Menu Utama}

Pada aplikasi simulasi vending machine, ada dua tipe user, yaitu user dan admin. Ketika aplikasi dijalankan, akan keluar Form Menu Utama seperti yang terlihat pada Gambar 10.

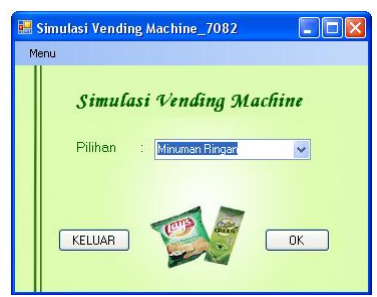

Gambar 10 Tampilan Form Menu Utama pada Aplikasi Simulasi Vending Machine

Ada dua jenis vending machine, yaitu vending machine minuman ringan dan makanan ringan. User dapat memilih jenis vending machine dengan memilih pada Combo Box pilihan, kemudian memilih tombol "OK". Jika memilih vending machine minuman ringan, maka Form yang tampil seperti pada Gambar 11. Sedangkan jika memilih vending machine makanan ringan, maka Form yang tampil adalah seperti pada Gambar 11.

\section{Form Simulasi Vending Machine}

Tampilan kedua Form Simulasi Vending Machine dapat dilihat pada Gambar 11. Karena pada dasarnya fungsi dan fasilitas yang terdapat pada kedua jenis Form Simulasi Vending Machine adalah sama, maka sebagai contoh, yang akan dibahas adalah Form Simulasi Vending Machine untuk makanan ringan.
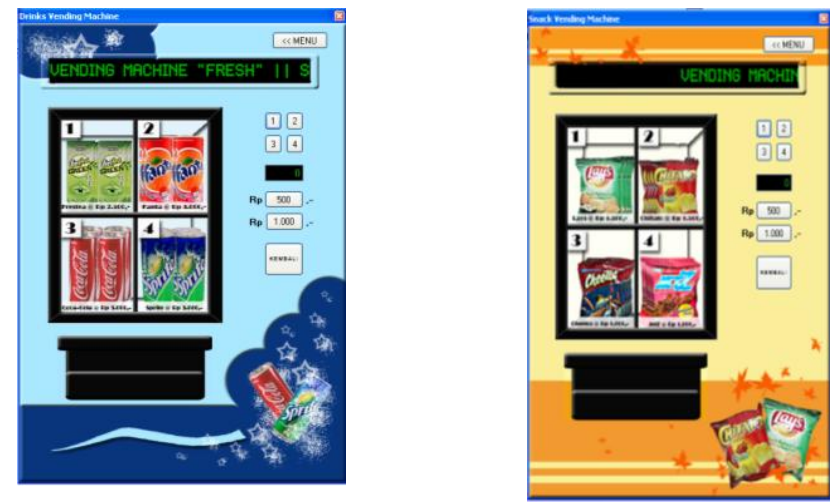

Gambar 11 Tampilan Form Simulasi Veding Machine Minuman dan Minu man Ringan 
Bila setelah Form keluar, user langsung menekan tombol 1, maka tidak ada output yang dikeluarkan. Pada saat tersebut, state berada pada q0. Sesuai dengan rancangan diagram state, maka proses yang terjadi pada state ini adalah seperti pada Gambar 14(a).
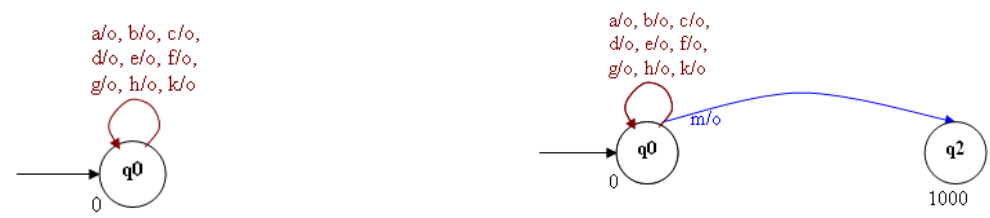

Gambar 14 (a) Proses Saat State Berada Di Q0, (b) Perpindahan State Setelah Uang 1.000 Masuk

Pada Gambar 14(a), bila input yang masuk adalah 'a' (tombol 1), maka outputnya adalah 'o' yang berarti tidak melakukan apa-apa. Dalam hal ini, output yang diberikan oleh aplikasi sudah benar. Selanjutnya, misalnya user memilih tombol Rp 1.000,- yang ada pada aplikasi, maka menurut diagram state, seharusnya state berpindah dari q0 ke q2. Pada state q2, nilai uang adalah 1.000, seperti yang terlihat pada Gambar 14(b). Sedangkan Text Box yang berfungsi sebagai counter juga menunjukkan angka ' 1000 ' seperti pada Gambar 15. Ini berarti, proses perpindahan state sudah benar.

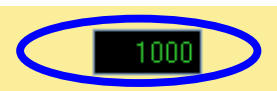

Gambar 15 Nilai Yang Ditunjukkan Oleh Counter Saat Uang 1.000 Masuk

Selanjutnya, apabila user memilih tombol '3', maka output yang akan keluar adalah makanan ringan Cheetos seperti pada Gambar 16(a). Bila dibandingkan dengan diagram state pada Gambar 16 (b), maka proses dan output yang dikeluarkan oleh aplikasi sudah sesuai dengan diagram tersebut.
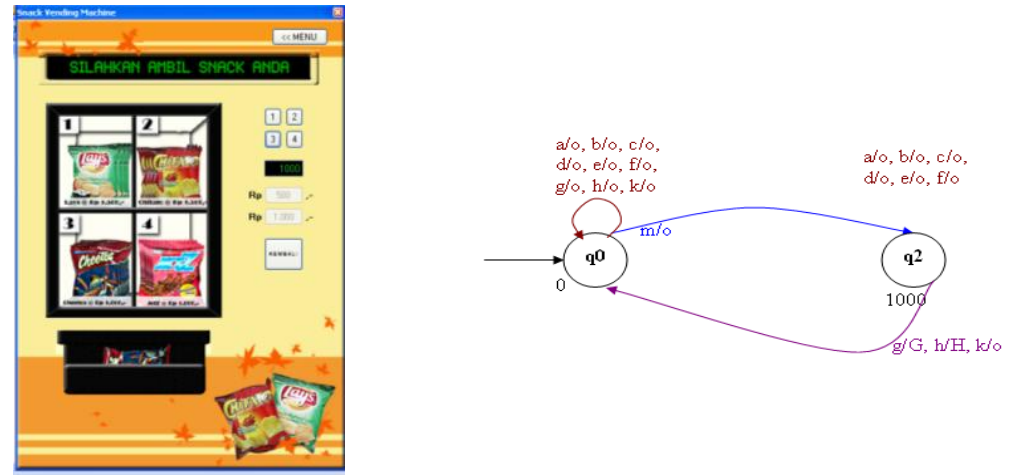

Gambar 16 (a) Output Ketika Tombol 3 Dipilih, (b) Diagram State Ketika User Memilih Cheetos

\section{Form Login Admin}

Tipe user admin memiliki hak untuk mengakses database yang berisi stok persediaan barang yang ada pada masing-masing vending machine.
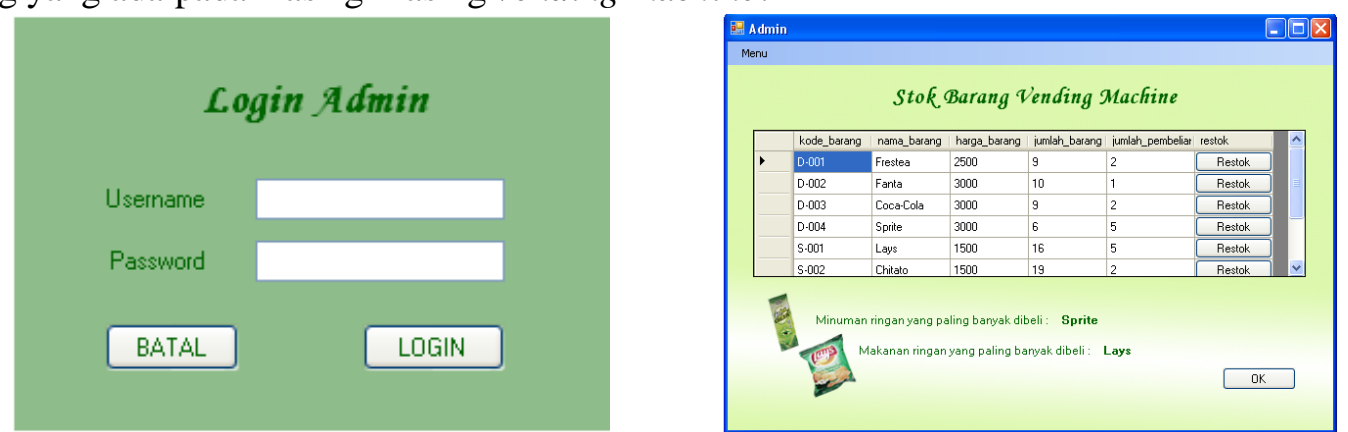

Gambar 17 (a) Tampilan Form Login Admin, (b) Tampilan Form Admin 
Untuk mengakses database tersebut, admin dapat memilih Menu Strip "Menu" pada Form Menu Utama dan memilih "Admin". Admin harus terlebih dahulu mengisikan username dan password pada Form Login Admin seperti pada Gambar 17 (a). Jika proses login berhasil, maka admin dapat melihat Form Admin yang tampilannya seperti yang terlihat pada Gambar 17 (b). Pada Form Admin ini, admin dapat melihat stok barang yang masih ada pada vending machine, jumlah pembelian tiap-tiap jenis barang, barang yang paling banyak dibeli, serta fasilitas re-stok untuk mengisi ulang persediaan barang yang sudah atau hampir habis.

\section{Simpulan}

Berdasarkan hasil perancangan dan implementasi Finite Automata pada simulasi vending machine, dapat diambil kesimpulan bahwa Finite Automata dapat dijadikan sebagai logika dasar untuk membuat simulasi vending machine. Lewat rancangan state diagram berdasarkan konsep Mealy machine yang telah dibuat, maka apliksi simulasi vending machine dapat dibuat dan hasil dari setiap input yang dipilih oleh user pada aplikasi sesuai dengan hasil rancangan tersebut. Aplikasi simulasi vending machine dibuat dengan tampilan dan cara kerja menyerupai vending machine asli, dengan tujuan agar user dapat memperoleh pengalaman dalam mengoperasikan sebuah vending machine serta mengetahui cara menggunakan sebuah vending machine.

\section{Daftar Pustaka}

[1] Nugroho, Aryo. Penggunaan Algoritma Greedy Dalam Aplikasi Vending Machine. 2007. Fakultas Teknologi Informasi Institut Teknologi Bandung.

[2] Utdirartatmo, Firrar. 2001. Teori Bahasa dan Otomata. Yogyakarta: J \& J Learning.

[3] Hariyanto, Bambang. 2004. Teori Bahasa, Otomata, dan Komputasi serta terapannya. Bandung: Penerbit Informatika.

[4] Sudkamp, Thomas A. 2005. Languages and Machines: An Introduction to the Theory of Computer Science. Boston: Addison Wesley Publishing Company.

[5] Sokolowsky, J.A, Banks C.M. 2009. Principles of Modelling and Simulation: A Multidisciplinary Approach. New Jersey: John Wiley \& Sons.

[6] Segrave, Kerry. 2002. Vending Machines: An American Social History. Jefferson: Mc Farland \& Company. 